New Delhi:MCl; 2002. Amended up to Oct 8, 2016. [cited 2018 Jul 14]. Available from: https://www.mciindia.org/CMS/rules-regulations/codeof-medical-ethics-regulations-2002

7. Barnett JC, Berchick ER. Health Insurance Coverage in the United States: 2016 Current Population Reports. 2017 [cited 2018 Jul 27]. Available from: https://www.census.gov/content/dam/Census/library/ publications/2017/demo/p60-260.pdf

8. Emergency Medical Treatment \& Labor Act (EMTALA), 2012 [cited 2018 Jul 27]. Available from: https://www.cms.gov/Regulations-andGuidance/Legislation/EMTALA/

9. Government of Canada. Health care in Canada. Modified Jul 11, 2017[cited 2018 Jul 14]. Available from: https://www.canada.ca/en/ immigration-refugees-citizenship/services/new-immigrants/new-lifecanada/health-care-card.html

10. Ministry of Public Health, Thailand. 11th National Health Development Plan 2012-2016 . 2012 Oct[cited 2018 Jul 13]. Available from: http:// www.nationalplanningcycles.org/sites/default/files/country_docs/ Thailand/11 ththailandnational_health_development_plan.pdf

11. O'Dwyer G, Konder MT, Machado CV, Alves CP, Alves RP. The current scenario of emergency care policies in Brazil. BMC Health Serv Res. 2013 Feb 20;13:70. doi: 10.1186/1472-6963-13-70.

12. Institute for Quality and Efficiency in Health Care(IQWiG). Health care in Germany: Health insurance in Germany [Internet]. 2018 [cited 2018 Jul 28]. Available from: https://www.ncbi.nlm.nih.gov/pubmedhealth/ PMH0078017/

13. Law Commission of India, 201st Report on emergency medical care to victims of accidents and during emergency medical condition and women under labour. 2006 Aug [cited 2018 Jul 12]. Available from: http://lawcommissionofindia.nic.in/reports/rep201.pdf

14. Thota $D$, George CK. Quality emergency medical care in India:Challenges \& opportunities. Working Paper 60/2005:1-20. Available from: https:// www.ihs.org.in/Publications/wp60.pdf

15. Guha S, Sethi R, Ray S, Bahl VK, Shanmugasundaram S, Kerkar P, et al. Cardiological Society of India:Position state/ment for the management of ST elevation myocardial infarction in India.Indian HeartJ.2017 Apr 1 [cited 2018 Jul 12];69(1):S63-97. Available from: https://www.sciencedirect. com/science/article/pii/S0019483217301876?via\%3Dihub

16. Khan A, Phadke M, Lokhandwala YY, Nathani PJ. A study of prehospital delay patterns in acute myocardial infarction in an urban tertiary care institute in Mumbai. J Assoc Physicians India. 2017 May [cited 2018 Jul
12]:65(5):24-7.

17. Kasturiratne A, Wickremasinghe AR, de Silva N, Gunawardena NK, Pathmeswaran A, Premaratna R, Savioli L, Lalloo DG, de Silva HJ. The global burden of snakebite: a literature analysis and modelling based on regional estimates of envenoming and deaths. PLoS Med. $2008 \mathrm{Nov}$ 4 [cited $2018 \mathrm{Jul}$ 12];5(11):e218. Available from: http://journals.plos.org/ plosmedicine/article?id=10.1371/journal.pmed.0050218

18. Chauhan R,Mazta S,Dhadwal D, Sandhu S. Indian public health standards in primary health centers and community health centers in Shimla District of Himachal Pradesh: A descriptive evaluation. CHRISMED J Heal Res [Internet]. 2016 [cited 2018 Jul 14];3(1):22. Available from: http:// www.cjhr.org/text.asp?2016/3/1/22/172390

19. Sodani $P$, Sharma K. Strengthening primary level health service delivery: Lessons from a state in India.J Fam Med Prim Care [Internet]. 2012 [cited 2018 Jul 14];1(2):127. Available from: http://www.jfmpc.com/text. asp?2012/1/2/127/104983

20. Citizen Charter of G B Pant Hospital,Government of Delhi.Date unknown [cited 2018 Jul 16] Available from: http://www.delhi.gov.in/wps/wcm/ connect/d8ac34004462961b8f39bf75d920f8b7/CitizenCharaterFinal. pdf?MOD=AJPERES\& $1 \mathrm{mod}=1347330896 \&$ CACHEID $=\mathrm{d} 8 \mathrm{ac} 34004462961$ b8f39bf75d920f8b7

21. Kerala Emergency Medical Services Project. 2010 [cited 2018 Jul 13]. http://www.arogyakeralam.gov.in/index.php/special-initiaves/kemp

22. The Telegraph Bureau.Consequences of hospital bill .The Telegraph.2017 Mar 3[cited 2018 Jul 14]. Available from: https://www.telegraphindia. com/1170303/jsp/calcutta/story_138694.jsp

23. Gadre A. India's private healthcare sector treats patients as revenue generators. BMJ. 2015 Feb 24; 350:h826. doi: 10.1136/bmj.h826.

24. Karan A, Yip W, Mahal A. Extending health insurance to the poor in India: An impact evaluation of Rashtriya Swasthya Bima Yojana on out of pocket spending for healthcare. Soc Sci Med . 2017 ; 181:83-92. doi: 10.1016/j.socscimed.2017.03.053. Epub 2017 Mar 27.

25. World Health Organization, World Bank. Tracking Universal Health Coverage: 2017 Global Monitoring Report. Geneva:WHO; 2017[cited 2018 Jul 13]. Available from: http://pubdocs.worldbank.org/ en/193371513169798347/2017-global-monitoring-report.pdf

26. Personal communication with and presentation by Indranil, Sharma $S$, Datta P, Selvaraj S. Changing landscape of private health care providers in India: implications for National level health policy. Presented at JSAOXFAM-PHRN Conference, New Delhi; January 2017.

\title{
Response to Jain et al on emergency healthcare in low resource areas
}

\section{PRABIR CHATTERJEE}

"Sustaining for-profit emergency healthcare services in low resource areas" by Jain et al (1) is an excellent reply to the Bawaskars (2). Clearly, the state must prevent both patients from going bankrupt and practitioners from running into negative balances.

However, two points made in the commentary are contestable:

\footnotetext{
Author: Prabir Chatterjee (prabirkc@yahoo.com), Community Health Doctor, 196 C/1. Picnic Garden Road, Kolkata 700 039, INDIA.

To cite: Chatterjee P. Response to Jain et al on emergency healthcare in low resource areas. Indian J Med Ethics. 2018 Oct-Dec;3(4) NS:336-7. DOI: 10.20529/IJME.2018.089

Manuscript Editor:Vijayaprasad Gopichandran.

OIndian Journal of Medical Ethics 2018
}

(i) "... how many doctors has anyone heard of slipping down the economic ladder? We would argue that the financial graph of almost all private physicians only moves upwards."

Is there any evidence to support this statement? Probably the income of private doctors in rural areas varies with the number and paying capacity of patients. In Eastern Europe (eg, Romania (3)) and in drought-hit areas-if the number of patients remained constant-the real income of doctors would fall with that of their patients. Any increase in income would be proportionate to that of the economic milieu or the number of patients seen.

(ii) "What place does the private sector occupy in the healthcare services scenario? Clearly, the expansion of private healthcare services has been in response to the ineffective and inaccessible 
public health system in rural areas, a process that acquired speed in the 1980s and galloped towards corporatisation after 2000."

Here, the rapid expansion of private services has been mostly in urban areas. Data is unlikely to show much private expansion in the rural areas. The push to go for higher end treatment is market driven, related to liberalisation rather than to an actual decrease in public facility performance or decrease in performance per unit population.

In 2016, there were 209,010 government beds in rural areas compared to 111,872 in 2005 (90\% increase). In the same period government beds in the urban areas saw only a $45 \%$ increase $(425,869$ in 2016 against 292,813 in 2005) $(4,5)$. So, there have always been more government beds in urban areas than in rural areas even though $69 \%$ population is in rural areas. But only $3 \%$ of the doctor population lives in rural areas (4). Since one third of government beds are in rural areas, and the existence of one third of government beds in rural areas presumably draws $30 \%$ government doctors to rural work, we can assume that $7 \%$ of doctors are government employees working in urban areas. It seems that the overwhelming majority of all doctors is in the urban private sector.

\section{References}

1. Jain Y, Patil SB, Phutke GB. Sustaining for-profit emergency healthcare services in low resource areas. Indian J Med Ethics. 2018 Oct-Dec;3(4) NS:334-6. DOI:10.20529/JME.2018.062. Available from: http://ijme.in/ articles/sustaining-for-profit-emergency-healthcare-services-in-lowresource-areas/.

2. Bawaskar HS, Bawaskar PH.Emergency care in rural settings: Can doctors be ethical and survive? Indian J Med Ethics. 2018 Oct-Dec;3(4):329-30. DOI: 10.20529/IJME.2018.038 . Available from: http://ijme.in/articles/ emergency-care-in-rural-settings-can-doctors-be-ethical-andsurvive/?galley $=$ html

3. Chiriac M. Romania raises medics'salaries to stem exodus. Balkan Insight. 2014 Jul 23. Available from: http://www.balkaninsight.com/en/article/ romania-plans-raising-salaries-for-health-professionals

4. Central Bureau of Health Intelligence. National Health Profile of India 2017. New Delhi: Directorate General of Health Services, MoHFW; 2017. Available from: http://www.cbhidghs.nic.in/index1.php?lang=1\&level= 2\&sublinkid $=87 \&$ lid $=1137$

5. Central Bureau of Health Intelligence. National Health Profile of India 2005. New Delhi: Directorate General of Health Services, MoHFW; 2005. Available from: http://cbhidghs.nic.in/index1.php?lang=1\&level=2\&su blinkid $=77 \&$ lid $=83$

\title{
Authors' response to commentaries on "Emergency care in rural settings"
}

\author{
HIMMATRAO SALUBA BAWASKAR, PRAMODINI HIMMATRAO BAWASKAR
}

We are grateful to Kattula (1) and Jain, Patil and Phutke (2) for their comments on our article on rural emergency medical care and our real problems in rural practice, their management and the threat to our survival (3). We agree with most of their points and the solutions they have advocated $(1,2)$.

However, since the medical profession has come under the purview of The Consumer Protection Act, 1986, fear of the hanging sword of the law has caused doctors constant stress, while their dedicated practice and interest in research are no longer of any value. To avoid legal liability, doctors are obliged to order several pathology investigations and expert opinions, which makes patients feel they are only profit-oriented, a belief

Authors: Himmatrao Saluba Bawaskar (himmatbawaskar@rediffmail.com) Bawaskar Hospital and Clinical Research Centre, Mahad, Raigad 402 301, INDIA; Pramodini Himmatrao Bawaskar (pramodinibawaskar@gmail.com), Bawaskar Hospital and Clinical Research Centre, Mahad, Raigad 402 301, INDIA.

To cite: Bawaskar HS, Bawaskar PH. Authors' response to commentaries on "Emergency care in rural settings" Indian J Med Ethics. 2018 Oct-Dec;3(4) NS:337.DOI:10.20529/IJME.2018.090.

( ) Indian Journal of Medical Ethics 2018 shared by the authors of the second commentary (2). They are not aware of what it costs to run a private hospital while providing ethical care. We have stood firm against industry sponsorship of doctors' participation in conferences and repeatedly fought against cut practice (4).

Today, rural government hospitals are often just buildings, with inadequate qualified staff including medical officers, and inadequate infrastructure. It is inevitable that the rural people are forced to depend on private healthcare. In this situation, unless there is universal health insurance for all, there will be no space left for the rural private healthcare providers.

\section{References}

1. Kattula D. Emergency care in rural settings: no easy solutions. Indian J Med Ethics. 2018 Oct-Dec;3(4) NS:331-3. DOI:10.20529/JMME.2018.059.

2. Jain Y, Patil SB, Phutke GB. Sustaining for-profit emergency healthcare services in low resource areas Indian J Med Ethics. 2018 Oct-Dec;3(4) NS:334-6. DOI:10.20529/IJME.2018.062.

3. Bawaskar HS, Bawaskar PH. Emergency care in rural settings: Can doctor be ethical and survive? Indian J Med Ethics. 2018 Oct-Dec;3(4)NS:329-30. DOI: 10.20529/IJME.2018.038.

4. Sachan D Tackling corruption in Indian medicine. Lancet. 2013 Nov 16; 382(9905): e23-4. 